\title{
Attitudes of Students towards the Study of Ghanaian Languages in University of Cape Coast
}

\section{Rita Akele Twumasi ${ }^{1}$}

* Correspondence:

rakeletwumasi@ucc.edu.gh

1. Department of Communication Studies, University of Cape Coast, Cape Coast, Ghana

Received: 14 October 2020

Revision: 10 December 2020

Accepted: 2 April 2021

Published online: 20 June 2021

\begin{abstract}
Learner attitudes towards a target language and its speakers as well as the use to which the language is put is fundamental in defining levels of success for the learning of that language. Ghana is dominated by several indigenous local languages. However, the official language as a medium of instruction in schools in Ghana is English language. Notwithstanding the use of English language as both official language and medium of instruction in our schools, disciplines specialize in the study of Ghanaian languages as a programme of study at the tertiary level. The study investigated the attitude that Ghanaian students have towards the study of Ghanaian indigenous languages and the motivational factors for the study of these languages at University of Cape Coast. Using a quantitative approach, the study employed 100 questionnaires which were administered to 50 Ghanaian language students and 50 nonGhanaian language students in the University of Cape Coast. First, the analysis showed that students have positive attitudes towards the study of Ghanaian indigenous languages. Second, students have instrumental reasons for the study of the language. The findings of the study have implications for theory and policy makers.
\end{abstract}

Keywords: Ghanaian language, language attitudes, language ideology, motivation 


\section{Introduction}

Language, according to Bodomo (1996), reflects societal realities such as social interactions, politics, and economics. Language is one of the most important means of supporting the interaction and communication between people from the same or different language backgrounds. Language helps bring communities together and, therefore, plays a critical role in society. In a sense, language can be considered a granary, a repository of the world-view of its speakers, and language can best contain and express the indigenous belief systems- socio-cultural, political, economic, and technological- of any society (Bodomo, 1996). If language is thought of as a repository and a tool for the expression and communication of these very socio-cultural, political, and economic belief systems of the society, then the study of Ghanaian local languages in Ghana should be a matter of concern since it is in these languages that identities are carried.

Language attitudes are very important in the learning and acquisition of second languages (Owu-Ewie \& EduBuandoh, 2014). People do have different attitudes towards the study of languages, especially when the nation is a multilingual one. Ghana is dominated by several indigenous local languages (Adika, 2012; Boadi, 1971; Gyasi Obeng, 1997; Kropp Dakubu, 1996; Owusu-Ansah \& Torto, 2013; Sackey, 1997). It is estimated that there are between 50 to 80 different indigenous languages in Ghana (Owusu-Ansah \& Torto, 2013). Eleven of the indigenous languages are government sponsored, and these languages are also supported by the Bureau of Ghana Languages. These government sponsored languages are Twi, Fante, Nzema, Ewe, Ga, Dangme, Dagbani, Dagaare, Gonja, Kasem, and Gurunne. Coulmas (2006) posited that in multilingual context, government selects one language for official and /or national purposes, leaving other languages that might be spoken in that country. Consequently, language conflict attitudes emerge as a result of competition, and some languages are threatened (Baker, 1992). For instance, because English is the official language in Ghana and it is used widely in education, it has endangered the indigenous languages and restricted the domains within which the local languages can operate (Guerini, 2008). Presently, without English, "there could not be full participation in the social, economic, and political life in the urban societies that are emerging" (Owusu-Ansah \& Torto, 2013, p. 67) as well as rural settings. In other words, as observed by Ngula (2014), several communicative activities are transacted in English, which is regarded the official and national language of the country.

Even though the use of the learner's primary language is advantageous, particularly at the early stages (Andoh-Kumi, 1994), the study of Ghanaian languages in our schools has become a thorn in the flesh of many educationists. Bamgbose (1991) found that this language issue is so serious that teachers of indigenous languages are not much sought after, and quite often, students do not consider them as proficient academically as teachers of other subjects. Andoh-Kumi (1997) reports that teachers have great respect for their colleagues in English Departments and all those who are very proficient in the use of English. Again, students also have very high respect and admiration for teachers who could use the English language proficiently. Thus, some lecturers who teach indigenous languages in most Ghanaian universities are despised by their colleagues in the same faculty. Consequently, the enrollment level and the levels at which these Ghanaian languages are studied in our colleges and universities have dwindled considerably.

Owu-Ewie and Edu-Buandoh (2014) report that, currently, in the Colleges of Education, Ghanaian language study is a core subject in the first year. It then becomes an elective in the second year for only a few students. At the tertiary level, there is a Department of Ghanaian Languages at the University of Education, Winneba, but at the University of Ghana and the University of Cape Coast, Ghanaian Languages and Linguistics are combined into a single department. Kwame Nkrumah University of Science and Technology, Kumasi has Ghanaian language studies as part of the Modern Languages Department. These universities offer Bachelor of Arts (BA) or Bachelor of Education (B. Ed), Master of Arts (MA), and Master of Philosophy (MPhil) programs in a Ghanaian language. University of Education, Winneba offers the BA in Fante, Nzema, Twi, Ga, Dangme, Gonja, Kasem, Dagbani, Gurene, Dagaare, Ewe, and recently Sisala. It also offers MPhil and MA programs in Akan (Fante and Twi), Ewe, and MA/MPhil in Ghanaian Language Studies (for Ga, Dangme, Nzema, Gonja, Kasem, Dagbani, Gurene, and Dagaare). The University of Cape Coast offers BA, MA, and MPhil in Akan (Fante and Twi) as well as in Ewe and Ga. KNUST offers only an undergraduate course in Akan, while University of Ghana offers BA and MPhil in Ga, Akan, and Ewe. It could be seen that the universities that offer some degree programmes in Ghanaian languages target only few languages, given that there are over fifty Ghanaian languages (Kropp Dakubu, 1996).

Increasingly, language ideologies are regarded as central to language policies (Ricento, 2006). Language policy itself is comprised not only of 'the explicit, written, overt, de jure, official and 'top-down' decision-making about language, but also the implicit, unwritten, covert, de facto, grass-roots and unofficial ideas and assumptions' about language in 
a particular culture (Schiffman, 2006, p. 11), or linguistic culture (Schiffman, 1996) which people may convey differently by expressing their attitudes towards it. Linguistic culture or language ideologies which are beliefs about language are inseparable from education, for at least two reasons. First, it is through mass education that language policies are carried out; second, education itself is conducted through language. Hence, a study of language to determine the attitudes of students towards such a language is very important. Underlining the relativity concept by Woolard and Schieffelin's (1994) is the issue of representation. Woolard (1998, p. 3) notes, 'representations, whether explicit or implicit, that construe the intersection of language and human beings in a social world are what we mean by "language ideology." Language ideologies, then, connect the linguistic with the social, and they do so in the interest of a particular, usually powerful, social position (Kroskrity 2000; Schieffelin et al., 1998). Since language ideologies are not simply about language, but also involve social and cultural conceptions of personhood, citizenship, morality, quality, and value, etc., these language ideologies have material effects in the world and thus are particularly important to understand.

Many people tend to have different attitudes towards languages, in general, and the study of it, in particular. Ajzen (1988, p. 4) proposed a definition of attitudes as "a disposition to respond favorably or unfavorably to an object, person, institution, or event." In the Longman Dictionary of Language Teaching and Applied Linguistics (1992, p. 199), 'language attitudes' are defined as follows: "the attitude which speakers of different languages or language varieties have towards each other's languages or to their own language. Expressions of positive or negative feelings towards a language may reflect impressions of linguistic difficulty or simplicity, ease or difficulty of learning, degree of importance, elegance, social status, etc. Attitudes towards a language may also show what people feel about the speakers of that language." In a similar vein, as postulated by Johnson and Johnson (1999, p.14) attitudes:

may be thought of as opinions, beliefs, ways of responding, with respect to some set of problems. They may not be formulated verbally until someone asks; they may not even be immediately available to common attention. They may be formed from haphazard experience. Or they may be the result of deliberate thought.

They may conform to cultural or peer-group norms or not.

It can be said that attitudes deal with how individual see and interpret things around them. In sum, language attitudes may be thought of as the feelings people have about their own language variety or the languages or language varieties of others. Language attitudes usually entail attitudes to the speakers of the particular language or dialect. For instance, language attitudes may influence sound change, how teachers deal with pupils and vice versa, and second language learning. Also, language attitudes may affect whether or not varieties are mutually intelligible. Language attitudes are fairly specific, low-level 'states' (mentalist) or 'responses' (behaviorist) or opinions. He thinks that language attitudes may be complex in that various people may react on multiple dimensions to an aspect of language and people may hold attitudes which seem to contradict each other and even themselves. Since attitudes are constructed based on past experiences (Allport, 1935), it could be postulated that attitudes toward local languages, language learning situations, and people who speak other languages are constructed. Therefore, if students receive a positive experience with other languages in their basic school education, they will develop positive attitudes toward those languages, toward school, and toward their classmates and these attitudes will be reflected in their later life and education (Lindholm-Leary \& Borsato, 2001; Navarra-Villarroel, 2011).

\subsection{Statement of the Problem}

According to Navarro-Villarroel (2011), the value of knowing more than one language is becoming recognized by schools. In Ghana, students learn English and use it frequently in many domains (Owusu Ansah \& Torto, 2013; Sackey, 1997; Sarfo, 2012), but very little is known about their attitudes towards the study of the local languages in universities in Ghana. According to ARED (2014), the mother tongue allows the child to verbalize his or her thoughts and to be in harmony with the world around him. Studies have, thus, been carried on attitudes of students towards the study of languages local languages, in particular (Guerini, 2007; Navarro-Villarroel, 2011; Owu-Ewie \& EduBuandoh, 2014). These studies did not pay attention to the study of local languages in the university, and whether students have positive attitudes towards the study of these languages, as well as the motivation for the study of these languages. Thus, I seek to fill this gap by investigating the attitudes of students towards the study of Ghanaian languages in a Ghanaian university. Specifically, the researcher examines whether students exhibit positive or negative attitudes towards the study of local languages in our universities, and the motivations behind these attitudes, using University of Cape Coast as a case study. 


\subsection{Research Questions}

The study is guided by the following research questions:

1. What attitudes do students demonstrate towards the study of local languages in University of Cape Coast?

2. What factors motivate students in the study of local languages in University of Cape Coast?

In the rest of the paper, I consider the Conceptual Framework, Empirical Studies, Methodology, and Analysis and Discussion.

\subsection{Conceptual Framework}

The concept of 'Motivation' underpins the study. Crookes and Schmidt (1991) define motivation as the orientation a learner has with respect to the purpose of learning a second language. For Kissau (2006), in the context of L2 learning, motivation is seen as the extent to which the individual works or strives to learn the language because of a desire to do so. Zanghar (2012) relates motivation to the drive to do something. So, motivation can be taken as the factors that motivate students to sustain a language and in this study, the language in reference is Ghanaian language.

Gardner and Lambert (1972) identified two main roles of attitudes: Instrumental motivation and integrative motivation. Instrumental motivation relates to the desire to receive social-status recognition or profitable benefits, and Gardner (1985) suggested that instrumental motivation is the stimulus for learning generated by utilitarian objectives upon the uses of the languages. Again, instrumental motivation emphasizes the importance of the functional reasons for learning the language such as getting a high-ranking job with a good salary (Gardner \& Lambert, 1972). Also, instrumental motivation is generally indicated by the aspiration to get practical benefits from the study of a second language (Hudson, 2000). It is thought of to be the purpose of learning a second language when the learner is not interested in interacting socially with new target language community members.

On the other hand, a student can be integratively motivated if he or she is inspired to learn, willing to join the other language group, and holds positive attitudes towards the learning process (Masgoret \& Gardner, 2003). Integrative motivation is a usual behavior of someone who appreciates the target language community, and studies the language for the reason of joining that community. Those integratively motivated students hold an internal motivation for learning the language (Gardner, 1985), and it is related to the desire to be integrated into another language community. These roles describe the position of students with respect to their language learning situation.

In sum, instrumental attitudes are when the student is learning the language for personal interest, and integrative attitudes are when the student is learning a language with the desire to be integrated into a specific community that speaks that language. Students learning a second language may report both instrumental and integrative attitudes in response to instruments measuring these attitudes (Gardner, 1985). I adopt this theory to enable me to identify the kinds of attitude that students exhibit towards the study of Ghanaian languages in the university and whether the factors that motivate them are instrumental or integrative.

\section{Review of the Literature}

Several studies have investigated language attitudes in various settings and at various levels of education. Such studies include Jordan (1941), Gardner and Lambert (1959), Momani (2009), Masgoret and Gardner (2003), Liao (2010), Sarfo (2012), Bani-Khaled (2014), Owu-Ewei and Edu-Buandoh (2014), Magwa (2015), and Dako and Quarcoo (2017).

For instance, many years ago, Jordan (1941) examined correlations between students' attitudes toward various school subjects and their corresponding performance in those subjects. French was among the subjects studied. This study was conducted in England, with students between 11 and 15 years old. The correlation between the school subject, French and students' attitudes toward it was the strongest one observed. Also, Gardner and Lambert (1959) studied whether Canadian high school students' attitudes toward French were related with their aptitude to learn the language. They found that the two were not related. In the same study, however, they found that students' integrative attitudes were strongly related with their French acquisition.

There have been other studies which have specifically concentrated on motivational variables which influence attitudes towards languages, especially in second language acquisition. Baker (1985) found that attitude toward 
language is related simultaneously with students' home-language and cultural background, as well as with other factors: age, gender, achievement, and type of school. Conducting a study in a Japanese university, Benson (1991) observed that students who have had little exposure to English, whose self-rating of their own skills exhibited extremely showed low morale. Also, the study found that integrative and personal reasons for learning English were preferred over instrumental ones. English was seen to be useful in the selection of modern functions, but not useful for domestic and local ones.

Bradford (2007) who also studied the motivational orientations toward learning English as a foreign language found that 168 students strongly confirmed orientations pertaining to pragmatic reasons for studying English, and were almost neutral toward identifying with native English speakers. In Fong (2004), 105 subjects who were used in the study expressed a positive attitude towards the English language, English culture, and English-speaking people and they liked the sound of the English language and their Chinese identity was not threatened even if they were good at English. The subjects in this study held a more instrumental orientation towards English and that they were willing to learn the language even if it was not a compulsory subject in school.

Buschenhofen (1998) who evaluated attitudes towards the use of English among year-12 and final-year university students in Papua New Guinea found that both groups almost exhibited positive attitudes towards English. Second, there were some significant attitudinal differences in relation to specific English language contexts. Closely related to the present study in terms of the setting is Sarfo (2012) who investigated the needs and feelings of Ghanaian university students towards English. He also examined the range of factors that motivate the students to study English. He used representative samples from two universities in Ghana, University of Ghana, Legon, and University of Cape Coast, Cape Coast. The study found that the motivations for studying English were more instrumental/utilitarian than integrative; however, students expected to see English becoming integrative in future.

Furthermore, Bani-Khaled (2014) examined attitudes and perceptions of 250 female students' towards the role of English. These students were enrolled in the BA in Applied English program at the University of Jordan. He obtained his data through semi-structured interviews with 50 of the students in addition to written self-reports submitted by 150 as compositions in university-level courses during the first semester of the academic year 2013-2014. The findings indicated that the overall attitudes of the students were unanimously positive towards the role of English in their lives. Also, he noticed that the attitudes of these students could be related to a number of intrinsic as well as instrumental factors, i.e. job market, personal development, cultural interaction, social status, travel, media, technology, and educational experience.

Quaicoe, Adams, Bersah, and Appiah Baah (2015) investigated how 280 students and 32 tutors randomly sampled from two Colleges of Education in the Western and Central Regions of Ghana perceive the study of Ghanaian Languages. A finding of the study was that Ghanaian Languages were not taught in very practical ways. Also, most students and tutors had a positive perception of students of Ghanaian Languages, and that students and tutors did not disrespect students offering Ghanaian Languages.

Other studies have also investigated the attitude of nationals (citizens) towards the use English language alongside indigenous languages. First, Magwa (2015) examined the attitudes of Zimbabweans towards the use of indigenous African languages as a medium of instruction in schools, colleges, and universities. Questionnaires, observations, document analysis, and interviews were used to collect data from 1000 participants, and the processing of the collected data was both qualitative and quantitative. The study revealed that English continued to be the prestige-laden language, but the indigenous languages had relatively low status. Also, the majority of the participants preferred English to be the medium of instruction in primary, secondary, and tertiary education because it was a language that gave power and prestige.

Similarly, Adriosh and Razi (2016) investigated the perception of Nigerian university students about the dominance of English over their indigenous languages and the role of the language policy of the country in this concern. Eight students were interviewed from two universities in the Northern side of Cyprus. The findings were that these students used English in both formal and informal contexts in their daily conversations. However, the students' use of the native language competence was decreasing gradually while mastery of the English language seemed to develop constantly.

Again, Ramachandran and Rauh (2016) sought to identify the factors that influenced individual preferences for the choice of the official language in Zambia. Data were collected in urban and rural individuals in Lusaka and Mbumpa 
Zambia. First, the study found that the informants did not greatly support the use of local languages in education and government administration. Also, the study revealed that the perceived ease of learning in a local language compared to English, and economic expectations in terms of effects on income were deemed important determinants of the preference for the use of a local language as official language. Again, the study revealed that individuals preferred the use of English as official language as against the use of the indigenous languages for fear of discrimination or disadvantages arising from the use of indigenous language.

Dako and Quarcoo (2017) also investigated individual attitudes towards bilingualism in English and a Ghanaian language. A total of 400 questionnaires were distributed to the managers of four different banks, Ghana Telecom, the Internal Revenue office in Tema, offices of the Tema Development Corporation, two insurance companies and the offices of Urban Roads were randomly surveyed, who then distributed them to their staff, but 120 questionnaires were retrieved. A finding of the study was that Ghanaians had a positive attitude towards English because it was the sole language that could enhance their chances of moving up the educational ladder and secured well-paid jobs. Another finding was that parents believed early exposure to English enhanced academic performance.

Furthermore, Sánchez, Mayer, Camacho, and Alzza (2018) explored language attitudes among speakers of Shipibo, an Amazonian indigenous language from the Panoan family, in the community of Cantagallo in the city of Lima, an urban, Spanish-dominant environment. Interviews were conducted based on questionnaires with two groups of participants in 2002 and 2017, 60 in total, focusing on their attitudes toward Shipibo and Spanish, with some of the participants answering the questionnaires both times, but others answering only once. Responses were analyzed quantitatively and qualitatively. A finding of the study was that the participants showed positive attitudes toward Shipibo-Konibo in 2002 and 2017, and strong identification with it, but language shift toward Spanish was now taking place, especially among the second generation. Another finding was that while in 2002 attitudes toward Spanish were mostly positive, in 2017, some negative attitudes toward the majority language emerged along with the perception of discrimination against the Shipibo-Konibo.

Attitude of individuals towards the use of indigenous and English languages has been studied not only at the university level but at the secondary school level as well. For instance, Owu-Ewie and Edu-Buandoh's (2014) study used semistructured interviews and observations as data collection strategies to investigate the negative attitude of Ghanaians towards the study of L1 in the senior High School (SHS), and how SHS students studying their L1 are coping with the negative attitude. The study also examined ways that the negative attitude towards the study of L1 in SHS can be changed. A finding of the study was that parents, school authorities, other language teachers and students, and the general populace have negative attitudes towards Ghanaian language study in the SHS, which were exhibited in what they say and in their actions and behaviors. The study concludes that concerted efforts, which could be achieved through educating people on the benefits of studying Ghanaian language, providing materials, and making the study of Ghanaian language a core subject in the SHS should be pursued to help change current attitudes towards the study of Ghanaian languages in the country.

In addition, Al-Sobhi, Rashid, and Abdullah (2018) explored the attitude of Arab secondary school students toward English spelling and writing. The 52-item attitude questionnaire administered to 70 Arab students studying English as a second language (ESL) in the Saudi School in Malaysia constituted the data for their study. The study found that the Arab ESL secondary school students had a high positive attitude toward English spelling and writing. Another finding was that the students had a higher attitude toward the Social Use of English, but less with their Creativity in writing.

Similarly, Nyamubi (2016) investigated the role of attitudes in secondary school students' performance in the English language, considering how learning English was impacted by students' interests and utilitarian attitudes to the language. The study involved students and teachers of English in six secondary schools in Morogoro Region. Data were collected through questionnaire and an achievement test. The study found that these students differed in terms of their mastery of English, scoring higher in the structure section, but composition was the most poorly scored section. While Form One students had more positive interest attitudes, Form Four students displayed more utilitarian attitudes to learning English, compared to Form One students.

Introducing another variable, gender, to previous studies on attitudes and language use, ZainolAbidin, PourMohammadi, and Alzwari (2012) examined whether there was any significant difference in the students' attitudes towards English language, based on their demographic profiles i.e., gender, field and year of study, found that, statistically, there was a significant attitudinal differences regarding gender and field of study but not year of study. 
Equally, Gajalakshmi (2013) investigated students' attitudes towards learning English language. A standardized questionnaire was administered in the form of normative survey to 600 students who were selected randomly from various high and higher secondary schools in Puducherry region in India. The study found a significant difference based on the gender, locality of the school, type of school, type of management.

Likewise, Elk1lic (2016) examined the attitudes of Kafkas University EFL students towards speaking skill and speaking classes as well as the differences with regard to their ages, genders, and grades. The subjects of the study were 80 EFL students in the Department of English Language and Literature at Kafkas University, among whom 43 were preparatory students and 37 were first year students, with 63 females and 17 males. The findings of the analysis showed that EFL students at Kafkas University had positive attitudes towards speaking skill and Classes. In addition, participants indicated that speaking skill was the most important of all, expressing their happiness in the study of speaking courses. However, the study found that there was no significant difference among their attitudes in terms of their genders, grades, and ages.

Last, Eshghinejad (2016) studied the attitude of male and female students of English as a foreign language (EFL), Kashan University, toward English language learning in terms of the behavioral, cognitive, and emotional aspects. Questionnaire survey was administered to 30 students who were randomly selected. The study found that respondents exhibited a positive attitude toward English learning in three aspects of behavioral, cognitive, and emotional. However, there were significant differences between males' and females' attitudes, with the mean of behavioral attitude among male students being higher while females showed a higher mean in cognitive and emotional aspects of attitude.

The studies reviewed examined student's attitude and nationals toward the acquisition and use of second languages, which implies that the subjects for the various studies had acquired first languages or local languages which they were already using, from the perspectives of nationals, and university and secondary school levels alongside other variables like gender. The focus of the present study is different from the approaches taken in the previous studies in that I aim to investigate students' attitudes towards the study of local Ghanaian languages in the universities, and not in the SHS as done (e.g. Owu-Ewie \& Edu-Buandoh, 2014). Specifically, attention will be paid to the kind of attitudes that students exhibit towards the study of local languages in the university and the motivational factors behind the study of these local languages in the university.

\section{Methodology}

This section considers methodology, focusing on the research design, academic setting, population, instrumentation and data, data collection procedure, and data analysis procedure.

\subsection{Research Design}

The study is a descriptive survey. This design enables researchers "to count when it cannot count every one, it counts a representative sample and then makes inferences about the population as a whole" (Oppenheim, 1999, p. 8). A major advantage of the descriptive survey is its potential to provide the researcher with a lot of information obtained from a large sample of individuals. Thus, the design is deemed useful in the present study since the researcher will be able to ascertain students' attitude toward the study of local languages in our university.

\subsection{Academic Setting}

The study was carried out in a Ghanaian university, precisely, University of Cape Coast. This institution was selected because the present study is about the attitudes of students towards the study of Ghanaian Languages at the university, and University of Cape Coast is a Ghanaian university that runs many programmes, including Ghanaian languages. Thus, the researcher stands to benefit from obtaining data for the present study. Besides, the issue of proximity is considered because the researcher is a member of this university community, and can, thus, really access pertinent data.

\subsection{Population}

The population consists of all level hundred students in University of Cape Coast and who are studying Ghanaian languages and Level Hundred students of University of Cape Coast who are not studying Ghanaian languages, specifically, Social Science students. It is assumed that students who are reading Ghanaian languages are already in the department, hence, even if they don't like the courses they are reading, they have little to say about it. Also, for now, the researcher would like to concentrate on attitudes of students who are outside the department. The study used 
the random sampling method technique, where all the elements in a population have equal chance of being selected (Cresswell, 2003; Fraenkel \& Wallen, 2000).

\subsection{Instrumentation and Data}

Hundred questionnaires were administered to Level 100 students, which were made up of the same items. This instrument was useful because it was amenable to statistical computations given the relatively large sample size of the study (Fraenkel \& Wallen, 2000). The questionnaires comprised closed-ended items on a Likert scale of four alternatives ( 1 = absolutely agree, 2 = quite agree, 3 = quite disagree, $4=$ absolutely disagree). The researcher adopted the items in the questionnaire from Buschenhofen (1998) and modified them to suit the current study since he is interested in looking at students' attitude towards the study of Ghanaian local languages at the university. The questionnaire was in three sections. Section A consisted of the demographics (age, sex, department, programme of study and level) of the participants. Section B was direct attitude questionnaire of thirty items while the motivation for the study was captured in Section $\mathrm{C}$, which comprised twenty-four items. The items of the questionnaire were arranged in a Likert scale of four alternatives $(1=$ absolutely agree, $2=$ quite agree, $3=$ quite disagree, $4=$ absolutely disagree). The number of items in the questionnaire totaled fifty nine (59): Section A has five items, Section B has thirty items, and there are twenty-four items in Section C.

\subsection{Data Collection}

For the collection of the data, first, the researcher consulted a lecturer at the Department of Ghanaian Languages, University of Cape Coast, and explained the purpose of the study to him. A week later, he took me to one of his classes, where I was introduced, and the purpose of the research explained to the students. Then, 50 questionnaires were distributed to the class. The students were given some minutes to fill them the same day and in class too. Later, with the help of the lecturer and two other teaching assistants, the filled questionnaires were collected, counted, and enveloped to avoid data loss. That same week, another lecturer of the Department of Communication Studies, University of Cape Coast also allowed me to distribute 50 questionnaires to his class after I had explained the rationale of the study to him. The same procedure used in distributing the questionnaires at the Ghanaian language class was repeated in this class that does not study any Ghanaian languages. Thus, the 100 questionnaires were ready for analysis.

\subsection{Data Analysis}

The data were analyzed, using basic descriptive statistics. For Jaggi (2010), descriptive statistics allow for presenting numerical facts or data in either tables, graphs or other visuals, and these graphical procedures summarize a collection of data in a clear and comprehensible way. This helps to simplify large amounts of data in a more sensible way. In short, descriptive statistics reduce a lot of data to a simpler summary. This method of analyzing data was adopted in this study for easier presentation of the responses to the items in the questionnaire in percentages and tables for easy interpretation of the data, bearing in mind the research questions.

\section{Results}

This section presents results of the analysis of the study, captured in two Tables, 1 and 2, which is in response to the two research questions posed earlier in the study. First, Table 1 offers a summary of attitude towards the study of Ghanaian languages. In other words, the table considers the attitudes and feelings of Ghanaian language/s and nonGhanaian language students towards the study of Ghanaian languages in the university, specifically, in University of Cape Coast (UCC). Table 1 presents percentages of responses of the two groups. The table presents the collated views on disagreement of the two category of students and leaves room for the responses on agreement to be inferred. The nature of the analysis does not warrant the presentation of both views (agree and disagree) on the same table. A summary of the responses on attitude towards the study of Ghanaian languages at the university is presented in Table 1 below. 
Table 1. Attitudes (and feelings) of students towards the study of Ghanaian languages

\begin{tabular}{|c|c|c|}
\hline Statement & $\begin{array}{l}\text { Ghanaian } \\
\text { Language } \%\end{array}$ & $\begin{array}{l}\text { Non-Ghanaian } \\
\text { Language } \%\end{array}$ \\
\hline I can't talk to speakers in other languages about general issues & 53.1 & 56.0 \\
\hline I can't talk to other foreigners for business/educational purposes & 59.2 & 71.4 \\
\hline It is not a requirement in our educational system. & 67.3 & 82.0 \\
\hline I will not need it at my work place. & 83.7 & 84.0 \\
\hline It is not the language of social advancement and mobility. & 60.4 & 78.0 \\
\hline It is not prestigious and a mark of an educated person. & 73.5 & 92.0 \\
\hline I can't study in a foreign language & 68.8 & 82.0 \\
\hline It is not the language of modernity. & 68.8 & 82.0 \\
\hline It will not make me a better person/famous person. & 79.6 & 89.8 \\
\hline $\begin{array}{l}\text { I can't use it in all domains of life, offering limited opportunities in } \\
\text { life. }\end{array}$ & 61.2 & 83.7 \\
\hline I can't read books and magazines that I read for pleasure. & 58.3 & 83.7 \\
\hline I don't like the speakers of the language. & 85.4 & 89.8 \\
\hline I don't like the places where these languages are spoken. & 85.4 & 91.8 \\
\hline It will make me behave and speak like the users of the language. & 77.1 & 81.2 \\
\hline I don't like it as my mother tongue. & 87.5 & 93.9 \\
\hline The Ghanaian language does not sound very nice. & 89.6 & 95.9 \\
\hline It is not a global language. & 31.9 & 42.0 \\
\hline $\begin{array}{l}\text { It does not allow me to express my thoughts well, when in a } \\
\text { conversation. }\end{array}$ & 74.5 & 79.6 \\
\hline My family and friends will scorn me. & 80.9 & 90.0 \\
\hline It is not one of the most crucial factors in Ghana's development today. & 58.3 & 67.3 \\
\hline I feel awkward and lack confidence. & 76.6 & 90.0 \\
\hline My status will not be raised among my friends. & 68.8 & 82.0 \\
\hline $\begin{array}{l}\text { I would not like to study a Ghanaian language even if it were a } \\
\text { compulsory subject at school. }\end{array}$ & 70.8 & 94.0 \\
\hline $\begin{array}{l}\text { I feel uncomfortable when I hear a student studying in Ghanaian } \\
\text { language. }\end{array}$ & 70.8 & 90.0 \\
\hline I feel uneasy when I hear a foreigner study a Ghanaian language. & 76.6 & 92.0 \\
\hline I am forced to study a Ghanaian language by the people around me. & 78.7 & 82.0 \\
\hline $\begin{array}{l}\text { When I hear someone study a Ghanaian language, I wish I could study } \\
\text { like him. }\end{array}$ & 39.6 & 34.0 \\
\hline $\begin{array}{l}\text { A Ghanaian language should be made part of the African studies } \\
\text { courses for all level hundred students. }\end{array}$ & 34.0 & 22.0 \\
\hline
\end{tabular}
courses for all level hundred students. 

language.

From Table 1 above, it can be observed that the percentages of the two groups were never the same at each item tested. Table 1 reveals that the percentages of the Non-Ghanaian language students, as weighed against each question, was higher than that of the Ghanaian language students. Again, in Table 1 the highest scores for the Ghanaian language students is $(89.9 \%)$, disagreeing with the point that the Ghanaian language does not sound very nice; this is followed by $87.5 \%$ - disagreeing that they don't like it as a mother tongue. What can be inferred from this is that these Ghanaian language students like the study of the mother tongue; thus, they are positive about the language because these students find themselves in the study of these languages. As found in the literature (Owu-Ewei \& Edu-Buandoh, 2014; Sarfo, 2012), learners' attitude adversely affect their performance in the study of that language, resulting in less preference of the study of the languages themselves. Second, the motivational factors for the study of Ghanaian languages in the university, in an attempt to answer Research Question 2 are presented, in percentages, in Table 2 below.

Table 2. Motivations towards the study of Ghanaian languages

\begin{tabular}{|c|c|c|}
\hline Statement & $\begin{array}{l}\text { Ghanaian } \\
\text { Language } \%\end{array}$ & $\begin{array}{l}\text { Non-Ghanaian } \\
\text { Language } \%\end{array}$ \\
\hline I can talk to other Africans for business and educational purposes & 26.1 & 34.7 \\
\hline $\begin{array}{l}\text { I can teach other Africans in the diaspora when they come back } \\
\text { home }\end{array}$ & 26.1 & 19.6 \\
\hline I can teach expatriates & 20.5 & 11.1 \\
\hline $\begin{array}{l}\text { I can speak and communicate fluently with others, especially } \\
\text { family and friends. }\end{array}$ & 24.4 & 8.9 \\
\hline It will bolster my cultural identity. & 23.9 & 10.9 \\
\hline It is part of our educational system. & 26.7 & 13.0 \\
\hline It can earn me a job. & 30.4 & 15.2 \\
\hline I do feel that I am a true Ghanaian & 26.9 & 13.3 \\
\hline I hope to further my education. & 30.4 & 15.6 \\
\hline It is a university requirement. & 45.7 & 23.9 \\
\hline For a personal development. & 23.9 & 13.0 \\
\hline To integrate with the Ghanaian culture. & 17.4 & 11.1 \\
\hline It will enable me to carry out my tasks more efficiently. & 26.7 & 15.2 \\
\hline It will make me a famous person. & 45.7 & 33.3 \\
\hline I will be praised by my family and friends. & 40.0 & 61.4 \\
\hline It will help me think and behave like a good Ghanaian & 39.1 & 17.4 \\
\hline I like the speakers of the language. & 19.6 & 17.4 \\
\hline Listen and understand those who speak it. & 22.2 & 10.9 \\
\hline Read textbooks, reports, articles in it. & 45.7 & 13.0 \\
\hline Write papers, reports and business letters in it. & 40.9 & 15.2 \\
\hline Read storybooks, magazines etc. & 47.8 & 13.0 \\
\hline
\end{tabular}


Write letters to friends and family members.

Listen to radio stations

Read announcements, advertisements, etc
41.3

19.6

28.3
21.7

13.0

15.6

From Table 2, it can be observed that, generally, the figures are not higher compared with the figures in Table 1. Another observation about Table 2 is that the scores for the Ghanaian language students are higher than the nonGhanaian language students. This situation is different from what was noted in Table 1, where the scores of NonGhanaian language students were higher than that of the Ghanaian language students. The only instance where the score for the Non-Ghanaian language students (61.4\%) was higher than the Ghanaian language students (40.0) is in relation to this statement: I will be praised by my family and friends. It is not surprising to have such a finding when respondents in, Table 1, have indicated that the study of a Ghanaian language at the university will not make them unpopular and their relations will not scorn them.

\section{Discussion}

First, with reference to the attitudes and feelings of Ghanaian language/s and non-Ghanaian language students towards the study of Ghanaian languages in the university, specifically, in University of Cape Coast (UCC), the lowest scores recorded by these Ghanaian language students were $31.9 \%$ and $34.0 \%$ - it is not a global language and A Ghanaian language should be made part of the African Studies courses for all level hundred students- respectively. First, what can be inferred from these scores in Table 1 above is that these Ghanaian language students agree that the Ghanaian language is not a global language, and this is a negative attitude towards the study of the Ghanaian language, confirming the findings of Dako and Quarcoo (2017), Owu-Ewie and Edu-Buandoh (2014), and Ramachandran and Rauh (2016) who found that their participants had a negative attitudes towards the study local languages in school. The students in the present study have some negative orientation towards the study of the language and they place less value on the study of the language as a global language. These Ghanaian language students would be justified in their response in the sense that the language of law, education, and judiciary in the country is English. For Achebe (1976), the world's language is English which may change in future but, for now, it is English. Maybe sometime later in the future, it will be a Ghanaian language but for now, no. So, the question remains: How can a Ghanaian language which does not even have national status have the status of a global language?

For the Non-Ghanaian language students, $94.0 \%$ was realized as the highest score. What can be said of this finding is that if the Ghanaian language is made a compulsory subject, this non-Ghanaian language students would like to study it. Fong (2004) identified a similar finding, for his subjects indicated that they were willing to learn the language even if it was not a compulsory subject in school. The next highest score was 93.9.0\%. With this figure, it can be inferred that these students have positive attitude towards the language as evident in the idea that they like the mother tongue.

From the table, $92.0 \%$ which is recorded against two question items also imply that these students have positive attitude towards the study of the language, by strongly disagreeing with the item that "the study of a Ghanaian language is not a mark of an educated person", and "I feel uneasy when I hear a foreigner study a Ghanaian language." Generally, it can be concluded that these non-Ghanaian language students, on the whole, have positive attitude towards the study of Ghanaian languages in the university. This finding is in line with the finding of Ting and Puah (2010) in that their results showed that the young Hokkien speakers are proud of their Hokkien identity and do not feel embarrassed about speaking Hokkien in front of others who do not share the same language with them. Quaicoe, Adams, Bersah, and Appiah Baah (2015) also had a similar finding where most students and tutors had a positive perception of students of Ghanaian Languages, and that students and tutors did not disrespect students offering Ghanaian Languages.

On the other hand, this positive attitude towards the study of Ghanaian languages in the university contrasts the findings of earlier studies that attitudes towards English were positive whereas attitudes towards the local languages were negative (Amissah et al., 2001; Dasai, 2001; De Klerk, 2000; Heugh, 2008; Kwofie, 2001). For Farr and Song (2011), English is the preferred medium of instruction in schooling and it is of wider communication, and local languages, like Ghanaian languages, are deemed unfit for use in formal, institutional, and official domains (Owu-Ewei \& Edu-Buandoh, 2014). 
Another study by Guerini (2007) showed that Akan is still viewed as subordinate to English. He noted that lecturers who taught Akan in most of the universities were looked down by their own faculty members as they (the Akan lecturers) were named as "second-rate" colleagues while Akan students were teased too. Magwa (2015) also found that, for Zimbabweans, English continued to be the prestige-laden language, but the indigenous languages had relatively low status.

Contrary to these higher scores, it can be seen from Table 1 above that these non-Ghanaian language students also recorded some low scores, which were $22.0 \%$ and $26.0 \%$ in disagreement to the points that "Ghanaian language should be made part of the African Studies courses for all level hundred students", and second, "before graduation, every student must study a Ghanaian language." It can be inferred here that a greater proportion of these non-Ghanaian language students agree to the assertions in these items, showing that they have a positive attitude towards the study of Ghanaian languages in the university.

The finding that respondents have positive attitude towards the study of Ghanaian languages contrasts the finding of Karahan (2007), whose respondents did not have strong positive attitude towards English; these students preferred the use of Turkish in their educational system. This was evident in the response of these Turkish students who supported the idea that English should not be the medium of instruction in their schools, and their course books, too, should not be in English. Maybe, the cultural settings and the orientations which they have received at home necessitated this.

On a comparative level, it can also be observed that though each of the student groups had lower marks for the items that were cast positively, the scores for the Ghanaian language students were greater than that of the Non-Ghanaian language students. These items tested on the favorable dispositions of students towards enforcement of the study of Ghanaian Languages in the university. For instance, where the Ghanaian language students had 41.7\%, the NonGhanaian language students had 26.0\%- Before graduation, every university student should study a Ghanaian language. It can be said that the non-Ghanaian language students are sound more positive than the Ghanaian language students, looking at the disagreement percentage that each one of them got. This finding contradicts the assertion by Owu-Ewei and Edu-Buandoh (2014) that the study of Ghanaian languages is not highly favored, alluding to the perception that Ghanaians, in general and students, in particular have negative attitudes towards the study of Ghanaian languages in our schools. The finding of this study also contradicts Ehala and Niglas' (2006) finding that students between 15 and 18 years of age living in rural areas had less positive attitudes toward the Estonian language (minority language) than students in urban areas, though I did not consider age. In an earlier study, Baker (1985) found that attitude towards language is related simultaneously with students' home-language and cultural background, as well as with age.

It can be argued that the findings of these study contradict the findings of Owu-Ewie and Edu-Buandoh (2014) perhaps because the subjects for the study are different - my subjects are level hundred students at the university level who might have been oriented on importance of language to individuals and the nation. As a result, they see the study of a Ghanaian language at the university level important. The subjects for the study in Owu-Ewie and Edu-Buandoh's (2014) also included teachers who might have graduated from the university and might have been introduced to importance of language learning. The problem is that the findings here are different because these graduate teachers are now working in the society which may have a certain ideology that individuals may have to subscribe to.

Certain structures are put in place that ensures the perpetuation of these ideas. So, Owu-Ewie and Edu-Buandoh (2014) found out that Fante students were not allotted classrooms, not respected, not provided with course materials and even, parents will not support in the study of these languages. Eventually, the good cherished ideas about the importance of languages, especially Ghanaian languages will vanish. This may explain why there were differences in the results. In this study, though family and friends were not involved in this study of Ghanaian language, it presupposes that family members will provide for children who are studying Ghanaian languages, unlike parents in Owu-Ewie and EduBuandoh (2014) study who will not support their wards at all when these wards of theirs study Ghanaian languages a school.

On the contrary, there was exception to these higher percentages in questions 28-30. With this, the non-Ghanaian language students recorded less percentages while the Ghanaian Language students recorded higher percentages. For example, in Question 28, Ghanaian language students had (39\%) and Non-Ghanaian language students obtained (34\%), unlike the other questions that have been discussed so far. The low percentages earned by this Non-Ghanaian language students cannot be blamed on them in the sense that as claimed by respondents in Owu-Ewia and EduBuandoh's study, parents have the view that their children could speak their local languages already; so, that was 
enough. Some of the students in that study also shared in that view, forgetting that the skills needed in the knowledge of a language includes not only speaking but reading, listening, and writing as well. Owu-Ewie and Edu- Buandoh (2014) themselves assert that the study of the Ghanaian language goes beyond the speaking of the language.

Second, having looked at the attitudes of students towards the study of the Ghanaian languages in the university, and linking these responses to what is the literature, the researcher will turn his attention to motivations for the study of Ghanaian languages in the university. With Motivation towards the study of Ghanaian languages in the university, it can also be seen in Table 2 that the highest score for the Ghanaian language students was $47 \%$, showing disagreement. It can, therefore, be inferred from Table 2 that these students are in agreement that reading story books and magazines is a factor for the study of Ghanaian language in the university. The next higher score is $45.5 \%$ "to read textbooks and reports; it is a university requirement, and it will make me famous." It can be seen that the motivations for studying Ghanaian languages at the university are more instrumental than integrative. On other hand, the least of the scores is $17.4 \%$ which is followed by $19.6 \%$ "to integrate with the Ghanaian culture, and I like the speakers of the language." This motivation or reason for the study of a Ghanaian language at the university is less of an integrative approach. This finding is similar to what Sarfo (2012) found in his study that the respondents in his study used English instrumentally than integratively.

For the non-Ghanaian language students, $61.4 \%$ was identified as the highest score, followed by $34.7 \%$ as the second highest score. The statements that were identified with these scores are this: 'I will be praised by my family and friends", and "I can talk to other Africans for business and educational purposes", respectively. These motivations are instrumental because the students are learning the language for personal interest and it is a positive attitude. Contrastively, it can be noticed that the lowest of the scores is $8.9 \%$ followed by 10.9 , with the statements these scores are attached to the statements: I can speak and communicate fluently with others, especially family and friends, listen and understand those who speak it, and it will bolster my cultural identity, a finding similar to Sánchez, Mayer, Camacho, and Alzza's (2018) that their participants had a strong identification with the Shipibo-Konibo language. These motivations are also instrumental since these students will study the language with a zeal to be able to use in life. Persistence in the study of a language is determined by motivation (Gardner, 2007). Bani-Khaled (2014) also found that the overall attitudes of the students were unanimously positive towards the role of English in their lives, relating the attitudes of these students to a number of intrinsic as well as instrumental factors like job market, personal development, cultural interaction, social status, travel, media, technology, and educational experience.

In sum, from the analysis, it was found that, in general, both Ghanaian language and non-Ghanaian language students have positive attitudes towards the study of Ghanaian languages in the university. But the attitudes of the nonGhanaian languages are more positive than the Ghanaian language students, which is evident in differences in the percentage scores of their responses. Second, these Ghanaian language and non-Ghanaian language students were more instrumental than integrative in their motivation of the study of Ghanaian languages in the university, meaning that these students are interested in studying the language for the uses that the study of the language offers rather than studying the language with integrative motivations.

\section{Conclusion}

The study examined the attitudes and feelings of students towards the study of Ghanaian languages in the university. The motivational factors for the study of Ghanaian languages in the university were also investigated. Employing a quantitative approach, the researcher distributed 100 questionnaire to 50 Ghanaian language students and 50 nonGhanaian Language students. A finding of the study was that non-Ghanaian languages are more positive than the Ghanaian language students towards the study of Ghanaian languages in the university. Another finding was that the Ghanaian language and non-Ghanaian language students were more instrumental than integrative in their motivation of the study of Ghanaian languages in the university.

The study has two broad implications - theory and policy making. First, many studies have been conducted to investigate attitudes of students towards the study of languages (Navarro-Villarroel, 2011; Sarfo, 2012). Some of these studies have concentrated on attitudes towards the use and motivation for the study of English as a second language or official language (Sarfo, 2012; ZainolAbidin et al., 2012). Others have also paid attention to attitudes towards the study of indigenous languages in schools (Owu-Ewie \& Edu-Buandoh, 2014; Zanghar, 2012). It is hoped that the present study adds to these existing studies by unearthing that both Ghanaian language and non-Ghanaian language students have positive attitudes towards the study of Ghanaian languages at the university, and the motivations for the study of Ghanaian languages at the university are more instrumental than integrative. For Zanghar (2012), motivation 
is often a good indicator of students' progress in learning language; thus, through this consciousness, we can work on enhancing those kinds of motivation that increase students' interest in the learning of Ghanaian languages and encourage these students to accomplish higher proficiency in Ghanaian languages.

It is recommended that further studies should investigate other levels and other courses of students in the same university to ascertain the attitude towards the study of Ghanaian languages in the university since motivation is an essential factor that plays a major role in achieving many fundamental goals in a student's academic life. Again, studies have shown differences in language attitudes towards the study of Ghanaian, along the parameters of gender and age (Bani-Khaled, 2014; Elkılıc, 2016; Eshghinejad, 2016). A further study can also investigate language attitudes across genders and ages, using students of university of Cape Coast. It is recommended that students, parents, school authorities, government, and the general public will help modify attitudes of students towards the study of Ghanaian languages at the university, in particular, and attitude towards the local languages, in general. Like Wamalwa, Adika, and Kevogo (2013), though the findings in their study indicated that the majority of students in Mtwara region displayed positive attitudes towards Kiswahili, more can be done to enhance the status of Kiswahili at school. The researcher also thinks that more can be done to improve upon the attitudes of students towards the study of Ghanaian languages at all levels of schooling.

As Gardner (2007) notes that motivation plays a crucial role in intensifying language programs, it is important that attention is paid to this. Such intensive language programs should not only be at the university level but they should be strengthened at all levels of education in the country. With this, Ghanaian languages will be promoted to share in the prestige English Language is currently enjoy in the country.

\section{References}

Achebe, C. (1976). Morning yet on creation day. Garden City, NY: Anchor Press.

Adika, G. (2012). English in Ghana: Growth, tensions, and trends. International Journal of Language Translation and Intercultural Communication, 1(1), 151-166. doi: https://doi.org/10.12681/ijltic.17

Adriosh, M. M., \& Razi, O. (2016). Investigating Nigerian university students' perception towards English language dominance over their indigenous languages. The Eurasia Proceedings of Educational \& Social Sciences (EPESS). International Conference on Research in Education and Science (ICRES), May 19-22 2016, Bodrum/Turkey.

Ajzan, I. (1988). Attitudes, personality and behavior. Chicago: Dorsey Press.

Allport, G. (1935). Attitudes. In C. Murchison (Ed.), A handbook of social psychology. Worcester: Clark University Press.

Al-Sobhi, B., Rashid, S., \& Abdullah, A. N. (2018). Arab ESL secondary school students' attitude toward English spelling and writing. Sage and Open Access, 8(1), 1-11. https://doi.org/10.1177/2158244018763477

Amissah, P., Andoh-Kumi, K., Asare-Amoah, S., Awedob. A., Mensah, F., Wilmot, E., \& Miske, S. (2001). IEQ2/Ghana final report: The implementation of Ghana's school language policy. America Institute for Research.

Andoh-Kumi, K. (1994). Topics in Ghanaian language education (Unpublished).

Andoh-Kumi, K. (1997). Language education policies in Ghana. Accra: Crigle.

Associate for Research and Education for Development (2014). The promotion and use of local languages in primary education in Senegal. A summary of the evaluation report on the impact of ARED model (Translation from French) (pp. 1-11).

Baker, C. (1992). Attitudes and language. Clevedon: Multilingual Matters.

Bamgbose, A. (1991). Language and the nation: The language question in Sub-Saharan Africa. Edinburgh: Edinburgh University Press for the International African Institute. 
Bani-Khaled, T. A. (2014). The role of English as perceived by students of applied English at the University of Jordan. European Scientific Journal, 10(5), 400-420. doi: 10.19044/ESJ.2014.V10N5P\%P

Benson, M. (1991). Attitudes and motivation towards English: A survey of Japanese freshmen. RELC Journal, 22(1), 34-48. https://doi.org/10.1177/003368829102200103

Boadi, L. A. (1971). Education and the role of English in Ghana. In J. Spencer, (Ed.), The language in West Africa (pp. 49-65). English Language Series. London: Longman Group.

Bodomo, A. (1996). African languages, linguistics, and literatures: Exploring global interdisciplinary research trends in the humanities. doi:10.13140/RG.2.1.1463.3127

Bradford, A. (2007). Motivational orientations in under-researched FLL contexts: Findings from Indonesia. RELC Journal, 38(3), 302-323. doi: https://doi.org/10.1177/0033688207085849

Buschenhofen, P. (1998). English language attitudes of final-year high school and first-year university students in Papua New Guinea. Asian Journal of English Language Teaching, 8, 93-116. https://www.cuhk.edu.hk/ajelt/vol8/rep2.htm

Coulmas, F. (2006). Sociolinguistics: the study of the speakers' choice. Cambridge: Cambridge University Press.

Creswell, J. W. (2003). Research design: Qualitative, quantitative, and mixed methods approaches (2nd ed.). Thousand Oaks, CA: Sage. http://www.sciepub.com/reference/159651

Crookes, G., \& Schmidt, R. W. (1991). Motivation reopening the research agenda. Language Learning, 41(4), 469512. https://doi.org/10.1111/j.1467-1770.1991.tb00690.x

Dako, K., \& Quarcoo, M. A. (2017). Attitudes towards English in Ghana. Legon Journal of the Humanities, 28(1), 20-30. doi: https://dx.doi.org/10.4314/ljh.v28i1.3

De Klerk, V. (2000). To be Xhosa or not be Xhosa: That is the question. Journal of Multilingual and Multicultural Development, 21(3), 198-215. doi: $10.1080 / 01434630008666401$

Desai, Z. (2001). Multilingualism in South Africa with particular reference to the role of African languages in education. International Review of Education, 47(3/4), 323-339. https://doi.org/10.1023/A:1017957927500

Ehala, M., \& Niglas, K. (2006). Language attitudes of Estonian secondary school students. Journal of Language Identity \& Education, 5(3), 209-227. https://www.etis.ee/Portal/Publications/Display/66f0b54e-3aa3-4f0ca0da-62bde5109e5e

Elkılıc, G. (2016). Attitudes of Kafkas University EFL students towards speaking skill and classes. International Journal of Humanities and Social Science Invention, 5(12), 62-67. http://www.ijhssi.org/v5i12(version\%204).html

Eshghinejad, S. (2016). EFL students' attitudes toward learning English language: The case study of Kashan University students. Cogent Education, 3(1), 1-13. http://dx.doi.org/10.1080/2331186X.2016.1236434

Farr, M., \& Song, J. (2011). Language ideologies and policies: Multilingualism and education. Language and Linguistics Compass, 5(9), 650-665. https://doi.org/10.1111/j.1749-818X.2011.00298.x

Fong, T. (2004). A study of secondary students' attitudes towards English. Unpublished MA thesis. University of Hong Kong.

Fraenkel, R. J., \& Wallen, E. N. (2000). How to design and evaluate research in education (4th ed.). San Francisco: McGraw-Hill.

https://www.scirp.org/(S(351jmbntvnsjt1aadkposzje))/reference/ReferencesPapers.aspx?ReferenceID=6489 80 
Gajalakshmi, A. (2013). High school students' attitude towards learning English language. International Journal of Scientific and Research Publications, 3(9), 1-7. http://www.ijsrp.org/researchjournal-0913.php

Gardner, R. C. (1985). Social psychology and second language learning: The role of attitudes and motivation. London: Edward Arnold.

Gardner, R. C. (2007). Motivation and second language acquisition. Porta Linguarum, 8, 9-20. doi: 10.30827/Digibug.31616

Gardner, R. C., \& Lambert, W. E. (1959). Motivational variables in second-language acquisition. Canadian Journal of Psychology/Revue canadienne de psychologie, 13(4), 266-272. https://doi.org/10.1037/h0083787

Gardner, R. C., \& Lambert, W. E. (1972). Attitudes and motivation in second language learning. Rowley: Newbury House.

Guerini, F. (2007). Multilingualism and language attitudes in Ghana: A preliminary survey. A paper presented at the international symposium on bilingualism (ISB6) which was held at the University of Hamburg (Germany) from the $29^{\text {th }}$ May to $2^{\text {nd }}$ of July, 2007.

Guerini, F. (2008). Multilingualism and language attitudes in Ghana: A preliminary survey. ETHNOREMA Lingue, Popolie Culture, 4(4), 1-27.

Gyasi Obeng, S. (1997). An analysis of the linguistic situation in Ghana. African Languages and Cultures, 10(1), 63-81. doi: 10.1080/09544169708717813

Heugh, K. (2008). Language policy and education in Southern Africa. In S. May \& N. H. Hornberger (Eds.) Encyclopedia of language and education: Volume 1: Language policy and political issues in education ( $2^{\text {nd }}$ ed.) (pp. 356-367). Springer Online.

Hudson, G. (2000). Essential introductory linguistics. New York: Blackwell Publishers.

Jaggi, S. (2010). Descriptive statistics and exploratory data analysis. India and Agricultural Statistics Institute, Library Avenue, New Delhi 110012.

Johnson, D. W., \& Johnson, R. (1999). Learning together and alone: Cooperative, competitive, and individualistic learning (5th edn). Boston: Allyn \& Bacon.

Jordan, D. (1941). The attitude of central school pupils to certain school subjects, and the correlation between attitude and attainment. British Journal of Educational Psychology, 11, 28-44. https://doi.org/10.1111/j.20448279.1941.tb02707.x

Karahan, F. (2007). Language attitudes of Turkey students towards the English language and its use in Turkish context. $\begin{array}{llllll}\text { Journal of Arts } & \text { Sciences, } & 7, & \text { 73-87. }\end{array}$ https://www.researchgate.net/publication/285696531_Language_attitudes_of_Turkish_students_towards_ the_English_language_and_its_use_in_Turkish_context

Kissau, S. (2006). Gender differences in second language motivation. Canadian Journal of Applied Linguistics, 9(1), 73-96. https://journals.lib.unb.ca/index.php/CJAL/article/view/19755

Kropp Dakubu, M. E. (1996). Language and community. Accra: Ghana Universities Press.

Kroskrity, P. V. (2000). Regimes of language: Ideologies, polities, identities. Santa Fe, New Mexico: School of American Research Press.

Kwofie, R. J. (2001). A pilot study of language attitudes among University of Cape Coast students. Unpublished long essay. University of Cape Coast, Cape Coast.

Liao, S. (2010). Identity, ideology and language variation. A sociolinguistic study of Mandarin in Central Taiwan. Unpublished $\mathrm{PhD}$ thesis. University Of California, Davis.

Lindholm-Leary, K. (2001). Dual language education. Avon, England: Multilingual Matters Ltd. 
Richards, J. C., Platt, J., \& Platt, H. (1992). Longman dictionary of language teaching and applied linguistics. London: Longman.

Magwa, W. (2015). Attitudes towards the use of indigenous African languages as languages of instruction in education: A case of Zimbabwe. Journal of Educational Policy and Entrepreneurial Research, 2(1), 1-16. https://www.iiste.org/Journals/index.php/JEPER/article/view/19017

Mamlawa, E. W., Adika, S. K., \& Kevogo, A. U. (2013). Multilingualism and language attitudes: Students' perceptions towards Kiswahili in Mtwara region of Tanzania. Research on Humanities $\quad$ and Social Sciences, $\quad 3(12), \quad 53-65$. https://www.researchgate.net/publication/334519862_Multilingualism_and_Language_Attitudes_Students_ Perceptions_towards_Kiswahili_in_Mtwara_Region_of_Tanzania

Masgoret, A. M., \& Gardner, R. C. (2003). Attitudes, motivation, and second language learning: A meta-analysis of studies conducted by Gardner and associates. In Z. Dörnyei (Ed.), Attitudes, orientations, and motivations in language learning: Advances in theory, research, and applications (pp. 167-210). Malden: Blackwell Publishing.

Momani, M. (2009). The Jordanian secondary stage students' achievement in reading comprehension according to their views towards learning English as a foreign language. Journal of Human Sciences, 42, 1-36. https://www.scirp.org/(S(351jmbntvnsjt1aadkposzje))/reference/ReferencesPapers.aspx?ReferenceID=1893 415

Navarro-Villarroel, C. (2011). Young students' attitude towards language. An unpublished Ph.D. thesis. Iowa State University.

Ngula, S. R. (2014). Corpus linguistics and language development in Ghana. Asian Journal of $\begin{array}{llll}\text { Humanities } \quad \text { and } & \text { Social } & \text { 522-534. }\end{array}$ https://www.ajouronline.com/index.php/AJHSS/article/view/1572

Nyamubi, G. J. (2016). Students' attitudes and English language performance in secondary schools in Tanzania. International Journal of Learning, Teaching and Educational Research, 15(2), 117-133. https://www.ijlter.org/index.php/ijlter/article/view/592

Owu-Ewie, C., \& Edu-Buandoh, D. F. (2014). Living with negative attitudes towards the study of L1 in Ghanaian Senior High Schools (SHS). Ghana Journal of Linguistics, 3(2), 1-25. https://doi.org/10.4314/gjl.v3i2.19

Owusu-Ansah, L. K., \& Torto, R. T. (2013). Communication of language attitudes: An exploration of the Ghanaian situation. The International Journal of Language Learning and Applied Linguistics World, 2(1), 65-76. https://scholar.google.com/citations?user=C-OheWIAAAAJ\&hl=en

Quaicoe, K., Adams, F. H., Bersah, V. A., \& Appiah Baah, K. (2015). Sociological variables perceived in the study of Ghanaian languages in Central and Western regional colleges of education in Ghana. Journal of Education and Practice, 6(33), 162-168. https://eric.ed.gov/?id=EJ1083499

Ramachandran, R., \& Rauh, C. (2016). Discriminatory attitudes and indigenous language promotion: Challenges and solutions. WIDER Working Paper, 78, 1-34. doi:10.35188/UNUWIDER/2016/121-5

Ricento, T. (2006). An introduction to language policy: Theory and method. Malden: Blackwell.

Sackey, J. A. (1997). The English language in Ghana: A historical perspective. In M. E. Kropp Dakubu (Ed.), English in Ghana (pp. 126-139). Accra: Black Mask Publishers.

Sánchez, L., Mayer, E., Camacho, J., \& Alzza, C. R. (2018). Linguistic attitudes toward Shipibo in Cantagallo: Reshaping indigenous language and identity in an urban setting. International Journal of Bilingualism, 22(4), 466-487. https://doi.org/10.1177/1367006918762164 
Sarfo, E. (2012). Ghanaian university students' attitude towards English. International Review of $\begin{array}{lllll}\text { Social Sciences } & \text { Humanities, }\end{array}$ https://www.academia.edu/2146763/Ghanaian_university_students_attitudes_towards_English

Schieffelin, B. B., Woolard, K. A., \& Kroskrity, P. V. (Eds). (1998). Language ideologies: Practice and theory. Oxford: Oxford University Press.

Schiffman, H. F. (1996). Linguistic culture and language policy. New York: Routledge.

Schiffman, H. F. (2006). Language policy and linguistic culture. In Ricento, T (Ed.), An introduction to language policy: Theory and method (pp.111-125). Oxford: Blackwell.

Ting, S. H., \& Puah, Y. Y. (2010a). Language attitudes of Hokkien speakers towards Hokkien and Mandarin. In Proceedings of the Borneo International Conference on Language and Literature: Unity in Diversity. Kuching: University Publication Centre.

Woolard, K. A. (1998). Introduction: Language ideology as a field of inquiry. In (Ed.) B. B. Schieffelin, K. A. Woolard \& P. V. Kroskrity, (Eds.) Language ideologies: Practice and theory (pp. 3-47). Oxford: Oxford University Press.

Woolard, K., \& Schieffelin, B. B. (1994). Language ideology. Annual Review of Anthropology, 23, 55-82. doi: https//doi.org/10.1146/annurev.an.23.100194.000415

ZainolAbidin, M., Pour-Mohammadi, M., \& Alzwari, H. (2012). EFL students' attitudes towards learning English language: The case of Libyan secondary school students. Asian Social Science, 8(2), 119-134. doi: 10.5539/ass.v8n2p119

Zanghar, A. (2012). Instrumental and integrative motivation among undergraduate Libyan students of English as a foreign language. Unpublished MPhil thesis. Colorado State University, Colorado. 